\title{
Localization of Human Antigen-Specific Helper and Suppressor Function in Distinct T-Cell Subpopulations
}

\author{
Cobi J. Heijnen, ${ }^{*}$ F. UytdeHaAg, ${ }^{*, 1}$ F. H. J. Gmelig-Meyling, ${ }^{*} \dagger$ \\ AND R. E. BALLIEUX ${ }^{*} \dagger$ \\ *Department of Immunology, University Children's Hospital, Het Wilhelmina Kinderziekenhuis, \\ Utrecht, The Netherlands, and $\dagger$ Department of Clinical Immunology. University Hospital. \\ Utrecht, The Netherlands
}

Received April 18, 1978

\begin{abstract}
Distinct human T-cell subpopulations were isolated and cultured in the presence of B-cells and antigens. After an incubation period of 6 days cells were tested for their capacity to secrete antigen-specific antibodies in the PFC-assay. The results indicate that the T-helper activity for the antigen-induced T-dependent B-cell differentiation is located in the T $\mu$-subpopulation, whereas the suppressor-cell activity is confined to the $\mathrm{T} \gamma$-subpopulation.
\end{abstract}

\section{INTRODUCTION}

Studies in mice have led to the recognition of subpopulations of lymphocytes with distinct surface alloantigens and functions (1). Evidence indicating an association between lymphocyte subpopulations with distinct surface characteristics and either helper or suppressor function, as has been established in the mouse, is still lacking for man. This is due in part to the lack of reagents recognizing surface alloantigens. However, the detection of receptors for the $\mathrm{Fc}$ fragments of IgM and IgG $\left(\mathrm{Fc} \mu \mathrm{R}^{2}\right.$ and FcyR, respectively) on different human T-lymphocyte subpopulations led to studies on the functional properties of the cell populations carrying these receptors (2-4).

Elegant work by Moretta et al. (4) has demonstrated that in the pokeweed mitogen (PWM)-induced human B-cell differentiation the T-helper activity resides in a population of T-cells bearing the $\mathrm{Fc} \mu \mathrm{R}$ (T $\mu$-cells). Under certain conditions $\mathrm{T}$-cells expressing $\mathrm{Fc} \gamma \mathrm{R}$ ( $\mathrm{T} \gamma$-cells) exert a suppressive activity in this in vitro $\mathrm{PWM}$ model. It is not yet known whether T-cells expressing help in the PWM-induced activation are identical to those providing antigen-specific help (5). However, results obtained in the PWM model strongly suggest that in antigen-induced B-cell activation too, helper and suppressor functions are located in different $\mathrm{T}$-cell subpopulations (4). Experimental confirmation of these assumptions has recently become possible with the development of methods for the induction of specific

1 This work was supported in part by the Foundation for Medical Research (FUNGO) which is subsidized by the Netherlands Organization for the Advancement of Pure Research (ZWO).

2 Abbreviations used in this paper: $F c R$, receptor for the $F c$ fragment of an immunoglobulin molecule; PWM, pokeweed mitogen; FCS, fetal calf serum; SE, sheep erythrocytes; OE, ox erythrocytes; OA, ovalbumin; $\mathrm{CH}$, cycloheximide; PFC, plaque-forming cell; a.c., adherent cell. 
antibody production in cultures of human peripheral blood lymphocytes (6-8). It has already been reported that antibody response in vitro to a number of antigens is T-dependent $(6,7,9,10)$. Furthermore, the existence in man of antigen-specific T-suppressor cells has recently been documented (11).

In this paper we present evidence indicating that antigen-specific suppressive activity is exerted by $\mathrm{T}$-cells of the $\mathrm{T} \gamma$-subpopulation, whereas antigen-specific helper cells were found in a T-cell population lacking the Fc $\gamma \mathrm{R}$.

\section{MATERIALS AND METHODS}

Lymphocyte isolation. From heparinized blood $(400-500 \mathrm{ml} ; 5 \mathrm{IU}$ heparin/ml) originating from healthy adult donors, mononuclear cells were isolated by density gradient centrifugation on Ficoll-Isopaque $\left(\rho=1.077 \mathrm{~g} / \mathrm{cm}^{3}\right)$ at $1000 \mathrm{~g}$ for $20 \mathrm{~min}$ (12) and then washed twice with MEM-Tris (Tris-buffered minimal essential medium, Gibco, Grand Island, N.Y.) supplemented with $5 \%$ fetal calf serum (FCS) (Gibco), penicillin, streptomycin, and fungizone (100 IU, $100 \mu \mathrm{g}$ and $25 \mu \mathrm{g}$ per $1 \mathrm{ml}$ MEM, respectively).

Monocyte depletion and isolation. Monocytes were isolated from the mononuclear cell suspension $\left(2 \times 10^{6}\right.$ cells $\left./ \mathrm{ml}\right)$ by allowing them to adhere to plastic Falcon flasks at $37^{\circ} \mathrm{C}$ in RPMI-1640 medium (Gibco) supplemented with $20 \%$ FCS. After 45-60 min of incubation, the supernatant containing the lymphocytes was decanted and the adherent cells (a.c.) were harvested by gently scraping with a rubber policeman and then collected in Earle's balanced salt solution (BSS) without calcium and magnesium (Gibco) supplemented with $0.002 M$ EDTA. The suspensions of a.c. thus obtained were usually contaminated with $5-15 \%$ lymphoid cells.

$T$-cell isolation and depletion. Sheep erythrocytes (SE) were washed three times and $160 \times 10^{6} \mathrm{SE} / \mathrm{ml}$ were incubated with $16 \mu \mathrm{l}$ neuraminidase (BoehringerMannheim) for $15 \mathrm{~min}$ at $37^{\circ} \mathrm{C}\left(\mathrm{SE}_{\mathrm{N}}\right)$, after which they were washed three times and counted. Lymphocytes and a 50-fold number of $\mathrm{SE}_{\mathrm{N}}$ were incubated for $5 \mathrm{~min}$ at $37^{\circ} \mathrm{C}$ in freshly siliconized glass tubes. The cell mixtures were then pelleted for 10 min at $200 \mathrm{~g}$ and incubated on ice for 45-60 min. The pellets were gently resuspended and centrifuged on a density gradient of Ficoll-Metrizoate $(\rho=1.090$ $\mathrm{g} / \mathrm{cm}^{3}$ ) for $30 \mathrm{~min}$ at $1200 \mathrm{~g}$. The T-cell pellet was freed of contaminating $\mathrm{SE}_{\mathrm{N}}$ by $\mathrm{NH}_{4} \mathrm{Cl}$-induced lysis followed by two washings with cold MEM-Tris-FCS 5\%.

The resulting cell suspension will be referred to as $T_{p}$ ( $T$-cells recovered from the $\mathrm{SE}_{\mathrm{N}}$-rosetted pellet). The B-cell enriched interphase was rosetted again with $\mathrm{SE}_{\mathrm{N}}$ and centrifuged on a density gradient as described above. This second interphase was used as a B-cell population.

$T \gamma$-cell isolation and depletion. To isolate $\mathrm{T} \gamma$-cells, $\mathrm{T}_{\mathrm{p}}$-cells were rosetted with ox erythrocytes (OE) sensitized with rabbit IgG antibodies (IgG-OE) (4). After rosetting, the pellets were centrifuged over a density gradient of Ficoll-Isopaque $\left(\rho=1.077 \mathrm{~g} / \mathrm{cm}^{3}\right)$ for $30 \mathrm{~min}$ at $1200 \mathrm{~g}$. The T $\gamma$-depleted cell fraction recovered from the interphase consisted of $\mathrm{T} \mu$-cells and lymphocytes lacking Fc $\gamma \mathrm{R}$ or Fc $\mu R$ ( $\mathrm{T}_{0}$-cells). Both the T $\gamma$-cells in the pellet, as well as the cells from the interphase, were freed of contaminating $\mathrm{OE}$ by lysis with $\mathrm{NH}_{4} \mathrm{C} 1$, after which the various cell fractions were washed in MEM-Tris-FCS 5\% and cultured overnight in MEM-Tris supplemented with $20 \%$ FCS.

$T \mu$-cell isolation and depletion. T $\mu$-Cells were isolated by rosetting the 
T $\gamma$-depleted population with OE sensitized with rabbit IgM antibodies (IgM-OE) $(2,3)$. The rosettes were centrifuged for $30 \mathrm{~min}$ at $1200 \mathrm{~g}$ over a density gradicnt of Ficoll-Isopaque $\left(\rho=1.077 \mathrm{~g} / \mathrm{cm}^{3}\right)$. The T $\mu$-cells in the pellet were recovered as described for the preparation of the $\mathrm{T} \gamma$-enriched cell fraction.

Surface markers. Surface Ig-positive (sIg) cells were identified by immunofluorescence using purified goat anti-human $\mathrm{F}\left(\mathrm{ab}^{\prime}\right)_{2}$ fragments conjugated with FITC (F/P ratio 2:6) and counted (13). For the identification of T-, T $\mu$-, and $\mathrm{T} \gamma$-cells, the lymphocytes were rosetted with $\mathrm{SE}_{\mathrm{N}}, \mathrm{IgM}-\mathrm{OE}$, and IgG-OE, respectively, as described above. Rosette counting was performed in a hemocytometer.

Cell cultures. Before culture, each cell fraction was washed twice with MEM-Tris containing antibiotics. Cultures were set up according to their original T/B-composition supplemented with $5 \%$ a.c. It was found that, although nonlymphoid mononuclear cells were always present in the B-cell-rich interphase fraction, the addition of $5 \%$ a.c., activated by adherence to plastic, increased the number of PFC to maximal values.

A total of $5 \times 10^{6}$ cells in a volume of $10 \mathrm{ml}$ was cultured in polystyrene Falcon tubes No. $2057(17 \times 100 \mathrm{~mm})$ at $37^{\circ} \mathrm{C}$ in a humidified atmosphere of $5 \% \mathrm{CO}_{2}$ in air. The medium consisted of RPMI-1640 supplemented with $2 \mathrm{~m} M$ L-glutamine/ml, antibiotics and $10 \%$ AB serum. The serum was extensively absorbed with SE and $\mathrm{OE}$ to prevent pseudo-plaque formation (14). Specific antibody production was induced against SE and ovalbumin (OA; Grade VI, Sigma Chemical Company, St. Louis, Minn.). For helper-cell induction $5 \times 10^{6} \mathrm{SE} /$ culture were used, whereas OA gave optimal results in a concentration of $3 \mu \mathrm{g} / \mathrm{ml}$. To induce suppressor activities $5 \times 10^{7} \mathrm{SE} /$ culture and $30 \mu \mathrm{g} / \mathrm{ml} \mathrm{OA}$ were used. Polyclonal antibody response was obtained with PWM, using a dose of $80 \mu \mathrm{g} / \mathrm{ml}$. After 6 days, the cells were washed twice and the plaque-forming-cell (PFC) assay was performed to identify antibody-secreting cells. Details of the culture conditions, the T-dependency, and the antigen-dose-dependency of the antibody response, have been described elsewhere $(6-8,10,11)$.

Plaque-forming-cell assay. This method has recently been described by Dosch and Gelfand (6). Briefly, SE were centrifuged for $5 \mathrm{~min}$ at $1000 \mathrm{~g}$ on the bottom of Falcon microtiter plates No. 3040 coated by incubation with poly-L-lysine (Sigma, $M_{\mathrm{r}} \leqq 100,000$ ) in a concentration of $100 \mu \mathrm{g} / \mathrm{ml}$ distilled water. Viable cultured cells in various dilutions were incubated for $60 \mathrm{~min}$ in the presence of SE- and OE-absorbed guinea pig complement (final dilution 1:20). In cultures where OA served as antigen, PFC were tested on a monolayer of OA-coated SE (15). PWM-stimulated cells were tested on a SE monolayer. Controls consisted of wells with cultured cells and heat-inactivated complement $\left(30 \mathrm{~min}, 56^{\circ} \mathrm{C}\right)$ or complement without cells.

The PFC formation being the result of antigen-induced specific antibody synthesis was tested for in various ways. During the last $24 \mathrm{hr}$ of the culture period, SE were added to cultures, stimulated with OA. Both the anti-SE and the anti-OA PFC response was determined. In a second approach free OA was added to the wells before OA-cultured cells were added to the monolayer. To determine whether the plaques resulted from an interaction of actively synthesized antibody with SE or OA-coated SE, $100 \mu$ g cycloheximide $(\mathrm{CH})$ was added to the cultures $18 \mathrm{hr}$ before harvesting. In this case the PFC assay was also performed in a medium containing $10 \mu \mathrm{g} \mathrm{CH} / \mathrm{ml}$. 
TABLE 1

Surface Markers on Isolated Subpopulations

\begin{tabular}{|c|c|c|c|c|c|c|c|c|}
\hline & \multicolumn{2}{|c|}{$\mathrm{SE}_{\mathrm{N}}(\%)$} & \multicolumn{2}{|c|}{$\operatorname{sIg}^{+}(\%)$} & \multicolumn{2}{|c|}{$\mathrm{IgG}-\mathrm{OE}(\%)$} & \multicolumn{2}{|c|}{$\operatorname{IgM}-\mathrm{OE}(\%)$} \\
\hline & $0 \mathrm{hr}$ & $24 \mathrm{hr}^{n}$ & $0 \mathrm{hr}$ & $24 \mathrm{hr}^{\prime \prime}$ & $0 \mathrm{hr}$ & $24 \mathrm{hr}^{\prime \prime}$ & $0 \mathrm{hr}$ & $24 \mathrm{hr}^{\prime \prime}$ \\
\hline PBL & 71 & 71 & 11 & - & 15 & 15 & 24 & 56 \\
\hline $\mathrm{T}_{\mathrm{p}}$ & 99 & $76^{\circ}$ & $<0.5$ & - & 11 & - & - & 51 \\
\hline B & - & $<0.5$ & 52 & - & - & - & - & 12 \\
\hline Ty-depleted & - & - & $<0.5$ & - & $<0.5$ & - & - & 72 \\
\hline $\mathrm{T} \mu$-enriched & - & - & $<0.5$ & - & $<0.5$ & - & 98 & $90^{h}$ \\
\hline T $\gamma$-enriched & - & - & $<0.5$ & - & 99 & $5^{b}$ & - & 10 \\
\hline
\end{tabular}

a $24 \mathrm{hr}$ at $37^{\circ} \mathrm{C}$ in RPMI + $20 \%$ FCS.

"After rosetting with erythrocytes and subsequent lysis with $\mathrm{NH}_{4} \mathrm{Cl}$, and $24 \mathrm{hr}$ at $37^{\circ} \mathrm{C}$. See Materials and Methods for techniques used for identification of the different lymphocyte populations.

\section{RESULTS}

\section{Surface Markers on Isolated Lymphocyte Subpopulations}

As shown in Table 1 the $\mathrm{T}$-cell fractions were essentially free of $\mathrm{sIg}^{+}$cells. The $\mathrm{T} \gamma$-depleted and the $\mathrm{T} \mu$-enriched fractions consisted for the greater part of cells rosetting with IgM-OE. When counted immediately after isolation and without dissociation of the IgG-OE rosettes, the T $\gamma$-enriched fraction showed more than $99 \%$ rosette-forming cells. When the rosettes were lysed and cells were cultured overnight at $37^{\circ} \mathrm{C}$, the formation of IgG-OE rosettes could no longer be obtained even after previous trypsinization of the lymphocytes (see Table 1). The B-cell population contained on the average $52 \% \mathrm{sIg}^{+}$cells; it always contained nonlymphoid cells $(5-15 \%)$ as determined by phase-contrast microscopy. The remaining mononuclear cells were considered to be null cells.

\section{Specificity of the PFC-Assay}

$\mathrm{T}_{\mathrm{p}}$-Cells are cultured with $\mathrm{B}$-cells, $5 \%$ a.c., and the antigens $\mathrm{OA}$ and $\mathrm{SE}$ in the optimal dose for helper-cell induction. Eighteen hours before testing PFC capacity, $100 \mu \mathrm{g}$ of $\mathrm{CH}$ was added to the cultures. In Table 2 it is shown that the plaque formation is abrogated in cultures containing $\mathrm{CH}$. This indicates that the observed

TABLE 2

Specificity of the PFC Assay

\begin{tabular}{ccccc}
\hline Tp-ly + B-ly $+5 \%$ a.c. & Antigen & CH & Free antigen in PFC assay & PFC/10 $l 0^{\prime \prime}$ \\
\hline $5 \times 10^{6}$ & $5 \times 10^{6} \mathrm{SE}$ & - & - & $985(583-2118)$ \\
$5 \times 10^{6}$ & $5 \times 10^{6} \mathrm{SE}$ & + & - & $48(30-62)$ \\
$5 \times 10^{6}$ & $3 \mu \mathrm{g} / \mathrm{ml} \mathrm{OA}$ & - & - & $1002(431-2622)$ \\
$5 \times 10^{6}$ & $3 \mu \mathrm{g} / \mathrm{ml} \mathrm{OA}$ & + & - & $62(40-82)$ \\
$5 \times 10^{6}$ & $3 \mu \mathrm{g} / \mathrm{ml} \mathrm{OA}$ & - & $+1000 \mu \mathrm{g} \mathrm{OA}$ & $122(80-162)$ \\
$5 \times 10^{6}$ & $3 \mu \mathrm{g} / \mathrm{ml} \mathrm{OA}$ & - & $+1000 \mu \mathrm{g} \mathrm{BSA}$ & $1080(460-2540)$ \\
\hline
\end{tabular}

"Mean of seven experiments. Figures in parentheses represent the ranges. 
TABLE 3

The Effect of the Addition of SE, Late in the Culture Period, on the PFC Response of OA-Stimulated Cultures of PBL ${ }^{a}$

\begin{tabular}{|c|c|c|c|c|c|c|c|}
\hline \multicolumn{2}{|c|}{$\begin{array}{l}\text { Antigen added to } \\
\text { cultures }\end{array}$} & \multicolumn{3}{|c|}{ Anti-SE PFC/ $10^{6}$ ly } & \multicolumn{3}{|c|}{ Anti-OA PFC/ $10^{6}$ ly } \\
\hline Day 0 & Day 5 & $I^{\theta}$ & $\mathbf{I I}^{o}$ & III $^{b}$ & $\mathrm{I}^{b}$ & $\mathrm{II}^{b}$ & III $^{b}$ \\
\hline OA & - & 42 & 102 & 31 & 1109 & 1395 & 1375 \\
\hline OA & SE & 24 & 100 & 57 & 1330 & 1583 & 1305 \\
\hline- & SE & 75 & 108 & 57 & 75 & 136 & 138 \\
\hline
\end{tabular}

a $5 \times 10^{6} \mathrm{PBL}$ of three different donors were cultured in the presence of an optimal dose of antigen (OA $3 \mu \mathrm{g} / \mathrm{ml}$; SE $5 \times 10^{6} /$ culture). Each experiment was carried out in six-fold; the mean values are given.

${ }^{b}$ Donor.

plaque formation is the result of actively synthesized protein. When $O A$ was used as antigen, $1000 \mu \mathrm{g}$ of free OA was applied to the OA-coated SE monolayer, just before the OA-sensitized cells and complement were added. Table 2 shows that the PFC response is almost completely inhibited in the presence of free OA but not of BSA, indicating that the observed plaque formation is OA specific. Finally, the results from experiments in which a nonrelevant antigen was added late in the culture period (Table 3 ) indicate that the generation of PFC is an antigen-dependent as well as an antigen-specific process, excluding the possibility of being the result of spontaneous or induced polyclonal response.

\section{T-Cell Dependency of the Antigen- and Mitogen-Induced Antibody Response}

In the initial experiments T-cells, B-cells, and reconstituted mixtures of $\mathrm{T}$ - and B-cells were cultured separately with PWM, SE, or OA (see Fig. 1). The results confirmed earlier reports that the induction of B-cell proliferation and differentiation into antibody-secreting cells is dependent on the presence of T-cells in the culture during the induction phase $(6,8,10)$.

\section{Identification of T-Helper Cells}

$\mathrm{T}_{\mathrm{p}}$-Cells were fractionated by rosetting with IgG-OE into a $\mathrm{T} \gamma$-enriched and a $\mathrm{T} \gamma$-depleted population, respectively. These cells from both fractions were cultured with B-cells and 5\% a.c. for a period of 6 days in the presence of SE, OA, or PWM in an optimal dose for helper-cell induction. The results shown in Fig. 2 indicate that the helper-cell activity resides in the $\mathrm{T} \gamma$-depleted cell population. PFC responses were even higher than when unfractionated $T_{p}$-cells were used in the cultures. Moreover, $\mathrm{T} \gamma$-enriched cells are not able to provide help in this assay.

The possibility was considered that the various separation procedures based on rosetting of lymphocytes with antibody-coated erythrocytes, could lead to false results obtained by comparing nonrosetting interphase cells and rosetted cells. Therefore, $\mathrm{T} \gamma$-depleted cells were rosetted with IgM-OE and the pellet fraction consisting of $\mathrm{T} \mu$-cells was cultured with B-cells, a.c., and antigen. The results of three such experiments indicate that the separation and reconstitution procedures did not give rise to significant changes in PFC responses (Fig. 3). Reconstitution of 


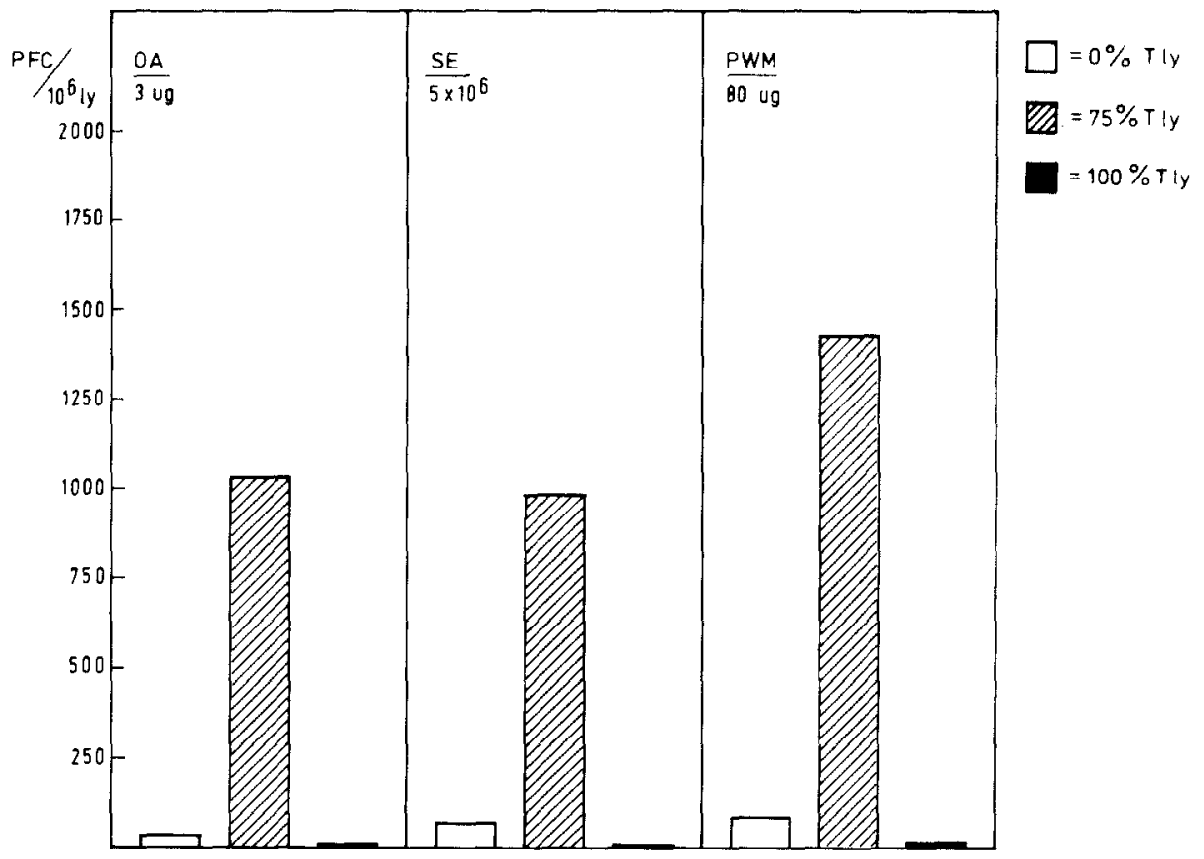

Fig. 1. T-Cell requirement for the generation of PFC. Cultures containing $5 \times 10^{6} \mathrm{~T}$-cells, $5 \times 10^{6}$ B-cells, or $3.75 \times 10^{6} \mathrm{~T}$-cells $+1.25 \times 10^{6} \mathrm{~B}$-cells were set up as described under Materials and Methods. OA, SE, or PWM were added to the cultures in a dose which is optimal for helper-cell induction. After 6 days the PFC assay was performed.

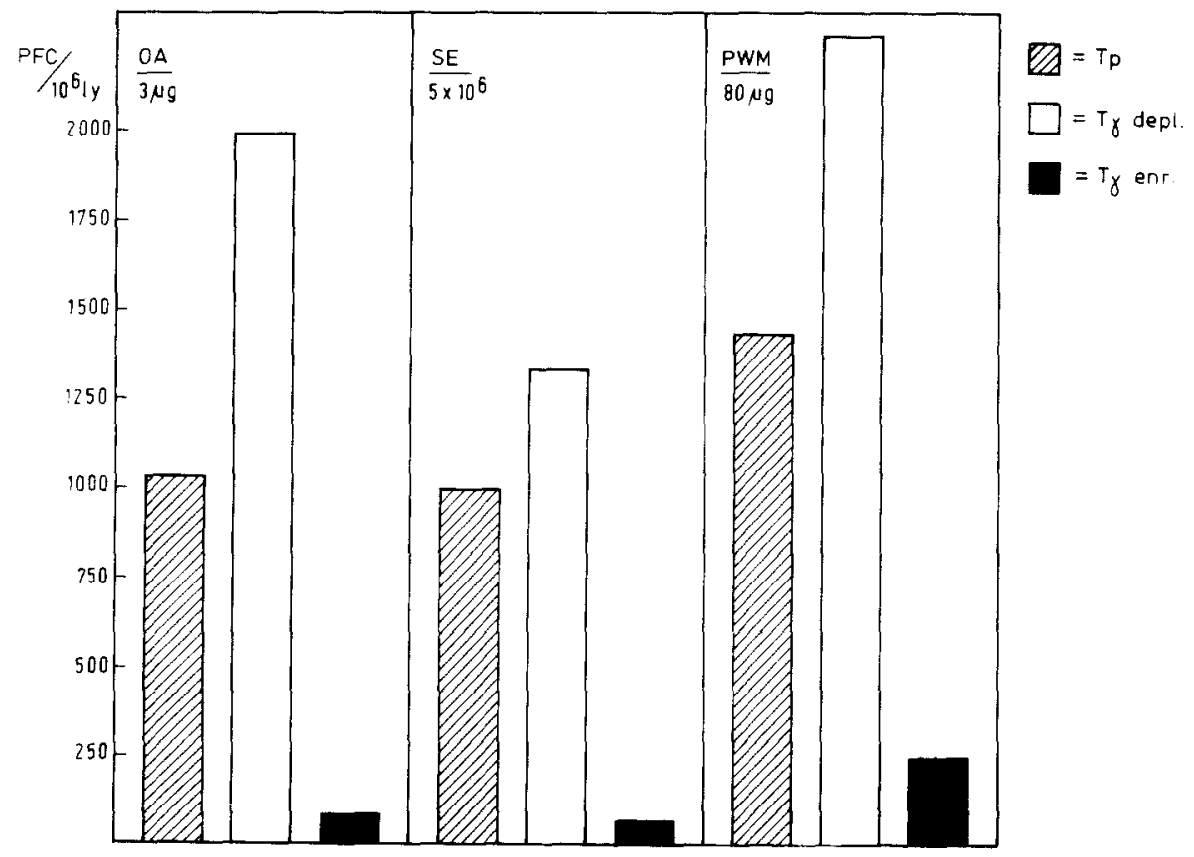

Fig. 2. Localization of $T$-helper activity. The $T_{p}$-fraction, the $T \gamma$-depleted fraction, and the T $\gamma$-enriched fraction were cultured with B-cells and $5 \%$ a.c. in the presence of optimal doses of the antigens, OA or SE, or the polyclonal stimulator PWM. After 6 days the PFC assay was performed. 


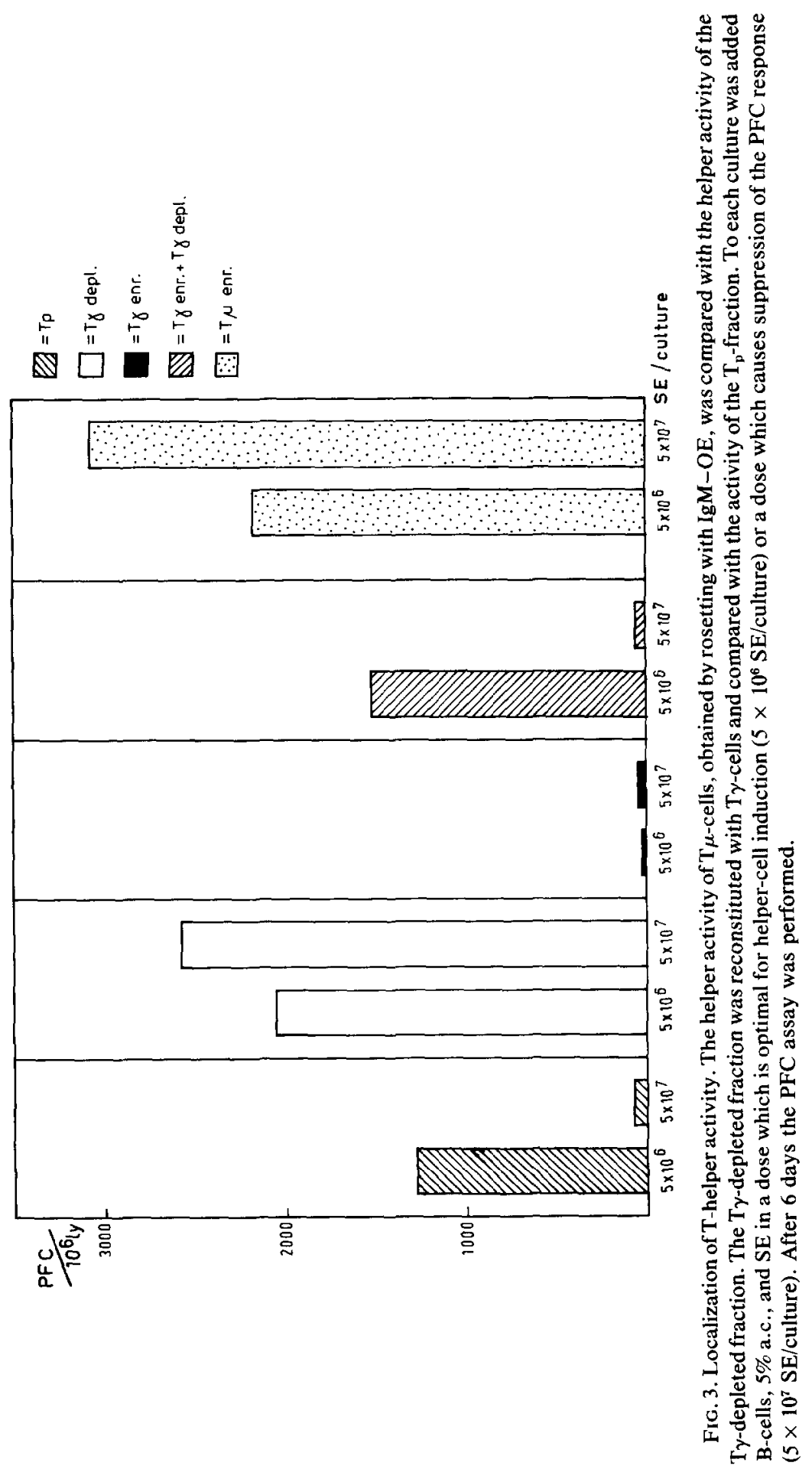


original $\mathrm{T} \mu / \mathrm{T} \gamma$-ratios also resulted in PFC responses comparable to the response of the $T_{p}$-fraction (Fig. 3).

\section{Identification of Antigen-Specific Suppressor Cells}

The level of the PFC response is significantly reduced by the use of a high dose of antigen during culture. This reduction can be attributed to T-cells that actively suppress the PFC response (11). T $\gamma$-Depleted cells, T $\gamma$-enriched cells, and the $\mathrm{T}_{\mathrm{p}}$-cell fraction were cultured separately with B-cells, a.c., and a high dose of antigen. Figure 4 shows that no suppression of the PFC response is obtained in cultures lacking $T \gamma$-cells, whereas cultures containing the $T_{p}$-fraction or the $\mathrm{T} \gamma$-enriched fraction were suppressed to almost baseline levels. Reconstitution of the $T_{p}$-cell fraction by recombining $T \gamma$-depleted and $T \gamma$-enriched cells in the appropriate $\mathrm{T} \mu / \mathrm{T} \gamma$-ratio, resulted in a suppression of the response (Fig. 4). These results, obtained in seven separate sets of experiments, strongly suggest that the antigen-specific suppressive activity resides in the $\mathrm{T} \gamma$-cell population.

\section{DISCUSSION}

The T-cell dependency of PWM-induced immunoglobulin production by human B-lymphocytes has been extensively documented by a number of authors $(5,16$, 17). A similar "'helper' function of T-cells was demonstrated for the production of specific antibodies in vitro by human peripheral B-cells after PWM stimulation (7, 18). These findings might be interpreted as the expression of T-cell help, analogous

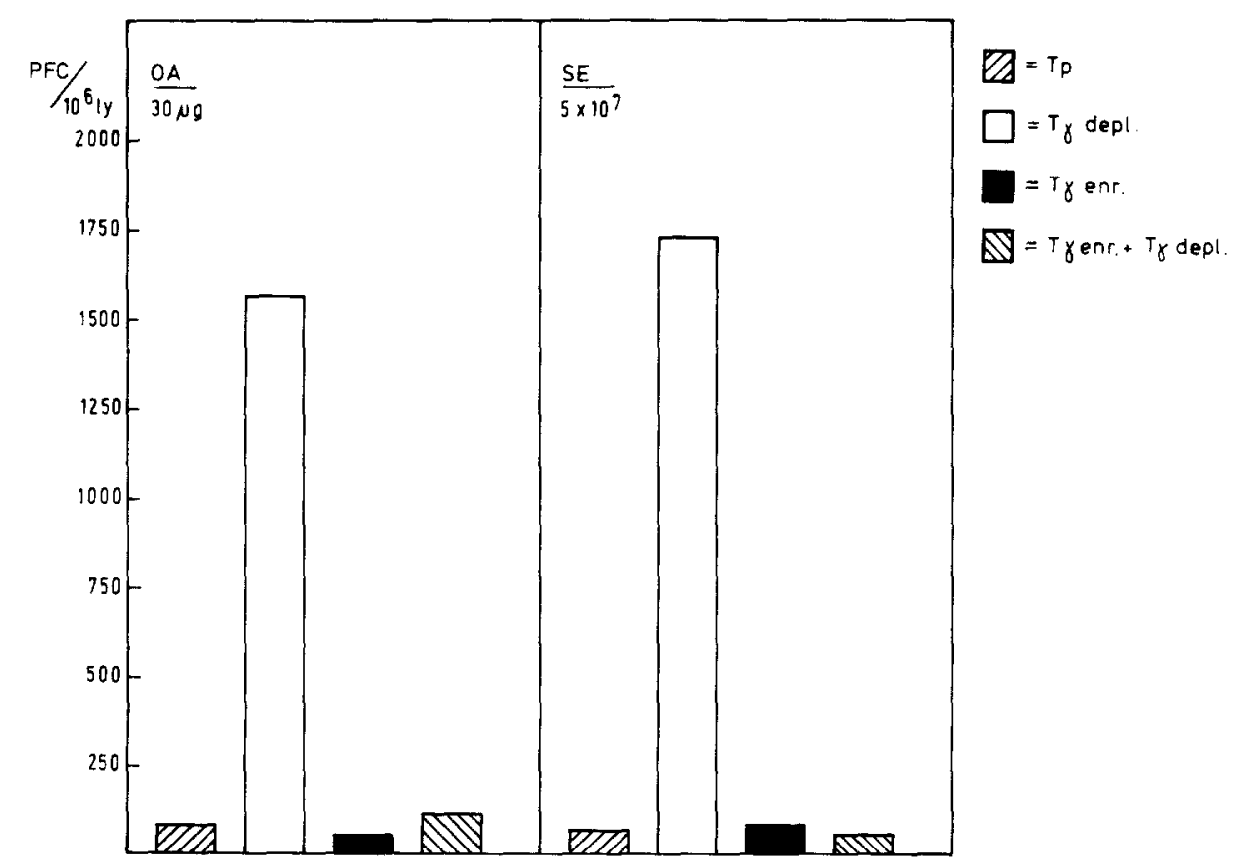

FIG. 4. Localization of T-suppressor activity. The $T_{p}$-fraction, the $T y$-depleted fraction, the $T \gamma$-enriched fraction, and the reconstituted $T_{p}$-fraction, consisting of $T \gamma$-depleted cells supplemented with approximately $11 \% \mathrm{~T} \gamma$-cells, were cultured with B-cells, 5\% a.c., and a high dose of antigen. After 6 days the PFC assay was performed. 
to that occurring in the course of an immune response to T-dependent antigens. Recent data on the T-dependency of antigen-induced antibody synthesis by human B-lymphocytes in vitro indeed indicate that the concept of antigen-specific helper cells, as already demonstrated in animal models, is also valid for man $(6,8,10)$.

The results of the present study dissect the complex events of cell collaboration in the humoral immune response somewhat further, since they show that helper function in the antigen-induced $\mathrm{PFC}$ response resides in the $\mathrm{T} \mu$-cell subpopulation. $\mathrm{T} \gamma$-Cells do not provide help in the process of antibody production by human B-cells in vitro. For practical reasons it was impossible to study a pure $\mathrm{T}_{0}$-cell population, because these cells could never be obtained without a considerable contamination of $\mathrm{T} \mu$-cells. Therefore, the possibility that $\mathrm{T}_{0}$-cells may also provide help cannot be excluded.

It is interesting to note that both $\mathrm{T} \gamma$-depleted and $\mathrm{T} \mu$-enriched cell fractions expressed greater helper activity than did $\mathrm{T}_{\mathbf{p}}$-cells. Similar observations were made by Moretta et al. (4) in the PWM model. It was suggested by these authors that the $\mathrm{T} \gamma$-subpopulation contained cells with suppressor activity.

In a separate study it could be demonstrated that antigen-specific suppressor cells could be induced in vitro by stimulation with a high dose of antigen (11). The present data show that this suppressive activity resides exclusively in the $T \gamma$ subpopulation. This finding explains why the PFC response is not suppressed at high antigen doses if $\mathrm{T} \gamma$-cells are absent in the culture. Indeed, the antibody response is even greater under these conditions (Figs. 3 and 4).

The significance of the $F c \gamma R$ for the suppression of the B-cell response is not clear. In mice as well as in man it has been shown that $\mathrm{T}$-cells release $\mathrm{Fc} \gamma \mathrm{R}$ which exert nonspecific suppression of the primary PFC response to SE in vitro $(19,20)$. The cells were found to be less suppressive after having lost their FcR (19). Cordier et al. (21) reported that the $\mathrm{Fc} \gamma \mathrm{R}$ is irreversibly lost by human T-cells after interaction with insoluble immune complexes. According to Moretta et al. (4) the "modulation" of the Fc $\gamma \mathrm{R}$ is an essential element in the induction of T-cell suppression, as measured in the PWM system.

We could confirm in the present study that after rosetting with IgG-OE, the $F c \gamma R$ on T-cells is lost (Table 1). Even after trypsinization or after a prolonged culture period, the cells did not restore their ability to form rosettes with IgG-OE complexes (data not shown). In spite of the absence of the Fc $\gamma \mathrm{R}$, "modulated" $\mathrm{T} \gamma$-cells were able to exert antigen-specific suppression (Figs. 3 and 4). However, in the present work as well as in other studies carried out in our laboratory, evidence was obtained that $\mathrm{T} \gamma$-cells can also act as suppressor cells without prior contact with immune complexes. So until now, we don't have evidence that the Fc $\gamma \mathrm{R}$ is directly involved in the suppressive activity of $\mathrm{T} \gamma$-cells. This is in agreement with our recent finding that human $\mathrm{T}$-suppressor cells produce a potent, antigen-specific suppressive factor, that is different from the $F c \gamma R^{3}$. Similar observations in mice have been published earlier by Kontiainen et al. (22).

It was interesting to find a subset of $\mathrm{T} \gamma$-cells that rosetted with the IgM-OE complex (Table 1), suggesting the presence of cells bearing receptors for both the Fc fragments of IgM and IgG. It remains to be established whether this observation

\footnotetext{
${ }^{3}$ UytdeHaag, F., Heynen, C. J., and Ballieux, R. E., Human B cell activation in vitro: Regulation by human $\mathrm{T}$ suppressor factors (in press).
} 
reflects a further heterogeneity in T-cells involved in suppression as suggested by Tada et al. (23) regarding the mouse system and as reported recently by Broder $e t$ al. (24) to be the case in man.

The detection of receptors for the Fc part of IgM on the majority of the T-lymphocytes raises the question of the biological significance of these membrane structures. Although an essential role of the IgM receptor in the helper function of $\mathrm{T} \mu$-cells is conceivable, there is no indication that interaction with $\operatorname{IgM}$ or IgM-erythrocyte complexes in the early phase of help is a prerequisite for efficient T-helper activity, since good antibody production was obtained when AB serum was substituted by serum from agammaglobulinemic patients in the culture medium.

It can be argued that on antigenic stimulation $\mathrm{T}$-independent $\mathrm{B}$-cells may be triggered to synthesize and secrete IgM antibody that could complex and bind to the $\mathrm{T} \mu$-helper cell (25). Preliminary results of experiments in which $\mathrm{T} \mu$-cells were removed from the culture $24 \mathrm{hr}$ after antigenic stimulation, indicate that adequate T-helper activity is obtained during this period, which again suggests that interaction of IgM with the IgM receptor is not necessary for antigen-specific triggering of $T \mu$-cells. ${ }^{4}$ This assumption could be confirmed in recent studies where $\mathrm{T} \mu$-cells were stimulated (in the absence of B-cells) with antigen for $24 \mathrm{hr}$. The culture fluid, collected after this period, could replace $\mathrm{T}$-cells in the induction of antigen-specific PFC response. ${ }^{3}$ In these experimental conditions it is unlikely that this T-helper factor is generated by contact of the Fc $\mu \mathrm{R}$ with IgM or IgM-antigen complexes.

It is interesting to note that comparable antibody responses were obtained when $\mathrm{T} \gamma$-depleted cells or $\mathrm{T} \mu$-enriched cells were reconstituted with $\mathrm{B}$-cells. The $\Gamma \mu$-cells were isolated by rosetting with $\mathrm{IgM}-\mathrm{OE}$, a process involving interaction of $\operatorname{IgM}$ with the corresponding receptor. Apparently, this interaction has no influence on the helper function of the $\mathrm{T} \mu$-cells under subsequent antigenic stimulation.

In conclusion the present data clearly establish that in man antigen-induced helper and suppressor activities are generated in distinct $\mathrm{T}$-cell subpopulations that can be recognized on the basis of receptors for $\mathrm{IgM}$ and $\mathrm{IgG}$, respectively.

\section{ACKNOWLEDGMENTS}

The authors are greatly indebted to Dr. H. M. Dosch and Dr. E. W. Gelfand, Hospital for Sick Children, Toronto, Canada for introducing to them the plaque-forming-cell assay. The valuable comments by Dr. B. J. M. Zegers and Professor J. W. Stoop, the expert technical assistence of Mrs. Ineke Dollekamp, and the secretarial assistence of Mrs. Joyce Lamberts are gratefully acknowledged.

\section{REFERENCES}

1. Cantor, H., and Weissman, I., Prog. Allergy 20, 1, 1976.

2. Moretta, L., Ferrarini, M., Durante, M. L., and Mingari, M. C., Eur. J. Immunol. 5, 565, 1975.

3. Gmelig-Meyling, F., Van der Ham, M., and Ballieux, R. E., Scand. J. Immunol. 5, 487, 1976.

4. Moretta, L., Webb, S. R., Grossi, C. E., Lydyard, P. M., and Cooper, M. D., J. Exp. Med. 146, 184. 1977.

5. Gmelig-Meyling, F., UytdeHaag, A. G. C. M., and Ballieux, R. E.. Cell. Immunol. 33, 156, 1977.

${ }^{4}$ Heynen, C. J., UytdeHaag, F., and Ballieux, R. E., Human B cell activation in vitro: Regulation by human $\mathrm{T}$ helper factors (in press). 
6. Dosch, H. M., and Gelfand, E. W., J. Immunol. 118, 302, 1977.

7. Fauci, A. S., and Pratt, K. R., Proc. Nat. Acad. Sci. U.S.A. 73, (10), 3676, 1976.

8. Delfraissy, J. F., Galanaud, P., Dormont, J., and Wallon, C., J. Immunol. 118, (2), $630,1977$.

9. Luzatti, A. L., Taussig, M. J., Meo, T., and Pernis, B., J. Exp. Med., 144, 573, 1976.

10. Heynen, C., and Ballieux, R. E., Proc. Dutch. Fed. Mtg. 18, 204, 1977.

11. UytdeHaag, F., Heynen, C. J., and Ballieux, R. E., Nature (London) 271, 556, 1978.

12. Bøyum, A., Scand. J. Clin. Lab. Invest. 21 (Suppl. 97), 77, 1968.

13. Gmelig-Meyling, F. H. J., Kooy-Blok, L., and Ballieux, R. E., Eur. J. Immunol. 4, 332, 1974.

14. Muchmore, A. V., Koski, J., Dooley, N., and Blaese, R. M., J. Immunol. 116, 1016, 1976.

15. Goding, J. W., J. Immunol. Methods 10, 61, 1976.

16. Keightley, R. G., Cooper, M. D., and Lawton, A. R., J. Immunol. 117, 1538, 1976.

17. Janossy, G., Gomez de la Concha, E., Luquetti, A., Snajdr, M. J., Waxdal, M. J., and Platts-Mills, T. A. E., Scand. J. Immunol. 6, 109, 1977.

18. Dosch, H. M., Percy, M. E., and Gelfand, E. W., J. Immunol. 6, 1959, 1977.

19. Fridman, W. H., Fradelizi, D., Guimezanes, A., Plater, C., and Leclerc, J. C., Eur. J. Immunol. 7, $230,1977$.

20. Molenaar, J. L., Van Galen, M., Hanneman, A. J., Zeylemaker, W., and Pondman, K. W., Eur. J. Immunol. 7, 230, 1977.

21. Cordier, G., Samarut, C., and Revillard, J. P., J. Immunol. 119, (6), 1943, 1977.

22. Kontiainen, S., and Feldmann, M., Eur. J. Immunol. 7, 310, 1977.

23. Tada, T., Taniguchi, M., and Tokukisa, T., In "IIIrd Ir-Gene Workshop, December 13-16, 1976" (H. O. McDevitt, Ed.). Academic Press, New York, 1978.

24. Broder, S., Poplack, D., Whang-Pang, J., Duran, M., Goldman, C., Muul, L., and Waldmann, T. A., N. Engl. J. Med. 298, 66, 1978.

25. Moretta, L., Ferrarini, M., Cooper, M. D., Contemp. Topics Immunobiol. 8, 251, 1978. 